\title{
Very rare disorders - organisation of care
}

\author{
Raoul CM Hennekam \\ From 5th European Conference on Rare Diseases (ECRD 2010) \\ Krakow, Poland. 13-15 May 2010
}

Care for patients and their families with rare disorders is gradually recognised as being essential both on an individual basis and on a population scale. Attention is usually paid to those with disorders with prevalence between one in 2,000 to one in 100,000. Not many official bodies realise that the majority of patients with rare disorders have in fact disorders that are much rarer, with a prevalence of one in 1,000,000 to one in $100,000,000$. This has consequences in providing the best care as the creation of support groups for such rare disorders is much more problematic, and centralisation of care cannot be established on a national level but only on a European level. This has wide-spread consequences, for instance regarding language, insurance, transportation, and research. The use of the internet to establish contacts, create Wikis around such rare entities, and to allow for e-mail consultations with medical experts elsewhere in Europe is emphasised and demonstrated using the entity Marshall-Smith syndrome (30 patients known in Europe) as an example.

The establishment of large centres of excellence for patients with very rare disorders has been suggested, either one in each country or one for around populations of 30,000,000 Europeans, to provide essential care and form a basis for further research.

Submit your next manuscript to BioMed Central and take full advantage of:

- Convenient online submission

- Thorough peer review

- No space constraints or color figure charges

- Immediate publication on acceptance

- Inclusion in PubMed, CAS, Scopus and Google Scholar

- Research which is freely available for redistribution

Submit your manuscript at www.biomedcentral.com/submit
C Biomed Central 